\title{
Spiritual care performed in a drug user clinic
}

\author{
O cuidado espiritual realizado em uma unidade de internação em adição
}

El cuidado espiritual realizado en una unidad de internación en adición

GE Revista Gaúcha

\section{Charlise Pasuch de Oliveira ${ }^{a}$ \\ Alessandra Mendes Calixto ${ }^{a}$ \\ Mitieli Vizcaychipi Disconzi ${ }^{b}$ \\ Leandro Barbosa de Pinhoc \\ Marcio Wagner Camatta ${ }^{c}$}

\section{How to cite this article:}

Oliveira CP, Calixto AM, Disconzi MV, Pinho

$\mathrm{LB}$, Camatta MW. Spiritual care performed in a drug user clinic. Rev Gaúcha Enferm. 2020;41(esp):e20190121. doi: https://doi.org/10.1590/19831447.2020.20190121 a Hospital de Clínicas de Porto Alegre (HCPA), Serviço de Enfermagem em Adição. Porto Alegre, Rio Grande do Sul, Brasil.

- Hospital de Clínicas de Porto Alegre(HCPA),Serviçode Enfermagem Ambulatorial. Porto Alegre, Rio Grande do Sul, Brasil.

Universidade Federal do Rio Grande do Sul (UFRGS), Programa de Pós-Graduação em Enfermagem, Porto Alegre, Rio Grande do Sul, Brasil.

\section{ABSTRACT}

Objective: To know the spiritual care practices of health workers in the context of an inpatient unit for the treatment of addictive disorders, aiming to incorporate an expanded care practice.

Method: Qualitative study considering the Convergent Care Research theoretical framework. The data collection occurred using semistructured interviews, with three rounds of conversations and informal chats with 14 health professionals, from July to November 2017. The analysis followed the steps of apprehension, synthesis, theorization and transference.

Results: Four categories emerged: respect for user ethical values; addressing the beliefs and values of professionals; the health professional-user relationship; and collective spiritual care. The main actions highlighted were individual (relaxation and prayer) and collective (meditation, spirituality and the 12 steps).

Conclusion: The rounds of conversations carried out in this research allowed workers to talk about spiritual care in addiction, to better understand its relevance to meet the needs of the patient.

Keywords: Spirituality. Substance-related disorders. Mental health. Mental health services. Nursing.

\section{RESUMO}

Objetivo: Conhecer as práticas de cuidado espiritual de trabalhadores de saúde no contexto de uma unidade de internação para 0 tratamento de transtornos aditivos, visando incorporar uma prática assistencial ampliada.

Método: Estudo qualitativo com referencial metodológico da Pesquisa Convergente Assistencial. Foram realizadas entrevistas semiestruturadas, três rodadas de conversas e conversas informais com 14 trabalhadores de saúde em uma unidade de internação em adição de julho a novembro de 2017. A análise das informações seguiu as etapas apreensão, síntese, teorização e transferência.

Resultados: Emergiram quatro categorias: evocação dos valores éticos dos trabalhadores; respeito às crenças e valores do usuário; encontro trabalhador de saúde-usuário e cuidado espiritual em grupo. As principais ações destacadas foram individuais (relaxamento e oração) e coletivas (meditação, espiritualidade e 12 passos).

Conclusão: As rodadas de conversas, realizadas nesta pesquisa, permitiram aos trabalhadores conversarem sobre o cuidado espiritual na adição, compreendendo melhor a sua relevância assistencial para atender às necessidades do paciente.

Palavras-chave: Espiritualidade. Transtornos relacionados ao uso de substâncias. Saúde mental. Serviços de saúde mental. Enfermagem.

\section{RESUMEN}

Objetivo: Conocer las prácticas de cuidado espiritual de los trabajadores de la salud en el contexto de una unidad de hospitalización para el tratamiento de trastornos adictivos, con el objetivo de incorporar una práctica de atención ampliada.

Método: Estudio cualitativo con referencial metodológico de la Investigación Convergente Asistencial. Se realizaron entrevistas semiestructuradas, tres rondas de conversaciones y conversaciones informales con 14 trabajadores de salud en una internación por adición de julio a noviembre de 2017. El análisis de las informaciones siguió las etapas de aprehensión, síntesis, teorización y transferencia.

Resultados: Surgieron cuatro categorías: respeto de los valores éticos de los usuarios; creencias y valores de la persona; relaciones profesional de salud-usuario; y cuidado espiritual en grupo. Las principales acciones destacadas fueron individuales (relajación y oración) y colectivas (meditación, espiritualidad y 12 pasos).

Conclusión: Las rondas de conversaciones, realizadas en esta investigación, permitieron a los trabajadores conversar sobre el cuidado espiritual en la adición, comprendiendo mejor su relevancia asistencial para atender las necesidades del paciente.

Palabras clave: Espiritualidad. Trastornos relacionados con sustancias. Salud mental. Servicios de salud mental. Enfermería. 


\section{口INTRODUCTION}

The negative consequences of the abuse of alcohol and other drugs have been identified as a public health problem in Brazil There are many challenges for the treatment of the complex problem that is addiction, since it is not restricted to the use of substances and their effects on the organism, but also involves psychosocial and spiritual issues ${ }^{(1)}$. Thus, Brazilian national health policies have been using a perspective of reducing social and health damage to meet the demands of people with problems related to drug abuse ${ }^{(2)}$.

Due to the complexity of the disease, it is important that any treatment integrates biopsychosocial and spiritual aspects. In this context, an international study showed that the treatment needs to include changes in habits, the rebuilding of family, social and spiritual relationships, in addition to work in the direction of stopping drug use. Thus, spirituality may increase the potential for adaptation and coping with the disease, reducing the level of stress and anxiety, and may prevent recidivism ${ }^{(3)}$.

Spirituality is part of human nature and has been scientifically recognized as an essential dimension in health care. Both the spirituality and the spiritual needs of the individual are essential components for achieving an integral health care.

Therefore, spiritual care is understood as the one that recognizes and responds to the needs of resilience, especially when faced with trauma, health problems or sadness. Although most health workers recognize the importance of spiritual aspects for the health and quality of life of users, few feel prepared to address and include the demands of the individual's spirituality in daily care(4).

Spirituality, especially when considered in health care, can indeed be a complex subject because it is permeated by many meanings and is often confused with religion. This theme is broad and involves the human dimension that expresses a personal search for meaning and purpose of life that transcends the reality of everyday life ${ }^{(5)}$. In turn, religion is configured as a system of beliefs, faith, rituals and practices developed to facilitate proximity with God, with the transcendent, the sacred, and usually offers a moral code of conduct ${ }^{(6)}$.

These dilemmas and anguish of workers when approaching the spiritual aspects of patients are also perceived due to the confusion generated in some of them, such as the fear of imposing their beliefs on the patient ${ }^{(5)}$. Considering these aspects, this research sought to answer the following question: What spiritual care practices are performed in the care of drug users?

This study aimed to know the spiritual care practices of health workers in the context of an inpatient unit for the treatment of institutionalized addictive disorders, to incorporate an expanded care practice. With the results of this research, there was a contribution to the reflection on spiritual care in the assistance provided for drug users. It is expected to suggest possibilities for the improvement of the care already offered in the unit, its findings capable of inspiring other similar services.

\section{METHOD}

This is a qualitative study that considered the Converging Care Research (CCR) approach as the methodological framework. The main characteristic of the CCR is to articulate assistance actions with scientific researches, so the activities can become research data sources for the production of changes in care practice, when necessary ${ }^{(7)}$.

This study was performed in an addiction in-patient unit (UIA) from the service of treatment of addictive behavior, specially drug use, a service that is part of the assistance provided by the General Hospital of Porto Alegre, Rio Grande do Sul, Brazil. It is a male inpatient unit with 22 beds, 20 destined to the public sector and two to private. The service is organized based on a treatment program that offers individual care and therapeutic groups, with a multiprofessional team composed of nine nurses, one nurse consultant in addiction, 22 nursing technicians, one nutritionist, three nutrition technicians, three nutrition assistants, one psychologist, one physical education teacher, seven psychiatrists, one occupational therapist, one social worker, four psychiatric medical residents, and 12 multiprofessional health residents - Drug User Integral Care Program (social work, nurse, occupational therapist, physical education professional, psychologist and nutritionist) — as well as interns from different professional categories.

The participants were 14 UIA health workers acting in the treatment program. The inclusion criteria were: a) working in the service for at least 3 months; b) being a health worker of the unit in accordance with the consolidation of labor laws or a resident of the multidisciplinary or medical area (psychiatry) of the addiction unit; d) being recognized by the team as someone who performs some action related to spiritual care. The exclusion criterion included those away from their job functions during the data collection period. The criteria to end the interviews was according to the snowball technique, that is the people indicated to be interviewed were pointed out by the surveyed workers themselves.

Data were collected from July to November 2017, to a total of 14 semi-structured interviews, informal conversations with the team, and three rounds of conversation, ending with the realization of a specific institutional training. 
The main technique for data collection was the semi-structured interview, with a pre-established script, addressing the conception of spiritual care, the actions developed, and the results identified in the practice of the health worker. These interviews were conducted at the interviewees own workplace and working hours, were recorded on a digital voice recorder and later transcribed in full to be analyzed.

For the interviewees choice, the snowball collection technique was used, so this choice was not made by the convenience of the researcher, thus enabling the workers themselves to indicate one or more colleagues that performed some spiritual care action. The choice of the first interviewee was intentional, based on the recognition of his work involving spiritual care practices. At the end of this interview, the researcher asked the interviewee to indicate new interviewees who performed spiritual care actions in the inpatient unit.

In CCR, informal conversations are less structured approaches that allow the researcher to establish a link between what is said to be observed in everyday work situations ${ }^{(7)}$. Thus, during the collection process, informal conversations were held in the lunch room, the nursing station, and the shift transference room with the intention of enriching the analytical repertoire of the study.

In this research, after the interview stage, three rounds of conversations were held with the unit's care team in different work shifts (morning, afternoon and evening), lasting one hour, regardless of their participation in the interview stage. This strategy was developed using the circle method, which is usually used to discuss the work process of health teams, aiming to improve assistance and lead to professional implications on the work produced ${ }^{(8)}$. These rounds were recorded and aimed to share ideas and reflect on the spiritual care performed and the possibilities of improvements in daily care.

From these data collection strategies, the participants proposed that the discussion during the research on spiritual care should be incorporated into the training matrix as a possibility to add and expand the research theme to other professionals of the unit. Thus, based on the demands, interests and needs identified by the participants, and aiming to have a greater understanding of spiritual care, while unfolding the research stages, an institutional formation course on the theme was conducted at three different times to enable the participation of all workers of the institution (morning, afternoon, and evening).

To perform the analysis of the information in this research, four steps were conducted: apprehension, synthesis, theorization, and transference ${ }^{(7)}$. The data were analyzed in the light of the scientific literature on spirituality and addiction, which made it possible to discuss spiritual care in the treatment of addiction.

The apprehension phase consisted of semi-structured interviews and data on informal chats and rounds of conversation. This stage, after information was apprehended, was the first moment of data analysis. In the synthesis phase, the relevant elements of the study were gathered, after an in-depth reading of the transcriptions and of the conversation rounds conducted, guided by a close look at the study objectives. The extracted information was organized into four categories.

In the theorizing stage, there was the process of identifcation, definition, and construction of relationships between a group of constructs in order to enable the production of predictions of the investigated phenomenon. From the information assembled in the synthesis phase, a literature immersion was conducted to define the category that emerged from the empirical material. There was a close relationship between theory and practice, enabling the design of the results seeking to discover the values in the information, and from there, the interpretation of data. Finally, in the transference phase, the meaning of the study results was attributed, contextualizing them to the reality studied with a view to transforming this reality (qualifying care practice), without the intention of generalizing them to other contexts. It was the final stage of the analytical process, which was directly linked to the research problem.

After authorization by the Research Ethics Committee of the General Hospital of Porto Alegre (under protocol number 68446517.0.0000.532), data were collected by signing the Free and Informed Consent Form (TCLE) as per the guidelines of the National Council of Health. Study participants were kept anonymous using the expression "E" (team), followed by a number indicating the order of interview (example: E4).

\section{- RESULTS AND DISCUSSION}

Fourteen health workers participated in this study, 12 are nurses, one psychologist and one nutritionist. There were 10 female respondents, ranging in age from 32 to 57 years, and having five to ten years of experience in the area of addiction. Five participanys declared spiritualism as their religion or spiritual belief, one declared to be Lutheran, two Catholics, two Buddhists, two evangelicals, one esoteric, and one agnostic.

Four categories emerged: addressing the beliefs and values of professionals; respect for the ethical values and beliefs of users; the health professional-user relationship; and collective spiritual care. 


\section{Addressing the beliefs and values of professionals}

Ethics is a set of principles, values, habits and practices that guide the private and social lives of people in a particular group. The study revealed that spiritual care practices performed by the team are linked to the recognition of ethical values. The statements of professionals meet the findings of the scientific literature by pointing out that spiritual care involves ethical values such as being kind, loving, respectful, compassionate, understanding, sensitive, and honest ${ }^{(9)}$. This becomes evident in the statements below:

Spiritual care is the exercise of patience, tolerance, respect, compassion, this is done on a daily basis, becoming a practice (E6).

Spiritual care is the development of tolerance, empathy, kindness, patience, and understanding (E7).

Work with empathy, calm, kindness, forgiveness, patience, values (E9).

Participants highlighted the importance of exercising and developing attitudes of patience, empathy, respect, tolerance and compassion in daily work, as elements that are part of spiritual care. These findings are in accordance with the literature, which shows that spiritual care takes into account and preserves people's ethical values. Thus, the team must respect the individuality of the person, not judging them, exercising a compassionate attitude, empathy and kindness, as attributes of spiritual care ${ }^{(10-11)}$.

Spiritual care begins with the worker's ethical attitude of being together, close to the person who is experiencing a delicate moment of stress and difficulty, such as being hospitalized. It is important to establish a relationship of trust and bond between user and worker in order to build a therapeutic relationship to provide well-being, optimism and hope.

Professionals reported that spiritual care involves approaching the person in a quiet way, exercising active listening and establishing dialogue. Therefore, it can assist the patient in giving meaning to suffering, as a way to develop hopes and strengths, thus helping patient motivation.

Providing comfort, hope, they arrive hopeless, wanting to die, we try to find a goal along with them to continue living (E1).

It has everything to do with the aspect of the bond (E3).

It improves the issue of bonding, not judging people who are not equal [...]. Listening attentively, establishing a good bond, not judging people. To stimulate hope in situations where everything is apparently destroyed (E7).

According to the statements described, the establishment of a relationship between health worker and patient, based on spirituality, develops the strengthening of bonds, dialogued relationships, sensitive listening, affection and appreciation of human dignity. When addressing health care for drug users, it is important to overcome the stigma and prejudice that make users be seen as dangerous, violent and solely responsible for their condition. Such prejudiced and stigmatizing posture restricts the possibilities of welcoming and giving access to people who have problems with drug abuse ${ }^{(12)}$.

Thus, the attributes of spiritual care can help professionals to overcome this drug user stereotype. Therefore, the right attitude should be a welcoming, empathic, sensitive one, that helps them to have a more optimistic attitude towards life. Spiritual care is linked to a person's ethics and sense of life purpose and helps in the quality of a therapeutic relationship through the caregiver sensitivity and the team effort and dedication to maintaining a positive and motivating environment during their time ${ }^{(13)}$.

Regarding the understanding of spiritual care performed in the addiction unit, the participants considered that it is linked to interpersonal relationships, which involves being willing to listen, without judgment and prejudice. This more positive approach meets some principles of motivational interviewing, which is a collaborative conversation style aimed at strengthening the patient motivation and commitment to change ${ }^{(14)}$. It is a proposal that reiterates the need for workers to interact and be interested in the patient history, thus valuing their potential. Respondents point out that the spiritual care is linked to active listening, showing affection, tenderness, attention and interest for the user and understanding how they deal with their spirituality.

I always try to be close, to create a relationship of trust and bond (E1).

I try to hear what they have to say, to know what's going on, how they deal with their spirituality (E2).

Attentive and respectful listening, because of the need to maintain motivation and hope (E3).

Firstyou have to listen, pat the patient, touch them with affection and show them im that we are there to help them (E8).

According to the statements, performing spiritual care helps in the establishment of a bond through active and 
respectful listening. Experiencing spirituality includes exercising faith, hope, compassion and solidarity, promoting awareness about the suffering of others and helping to find meaning for one's own existence. Thus, health professionals need to provide care that values spiritual support, so that the person can experience difficult moments with serenity ${ }^{(15)}$.

\section{Respect for the ethical values and beliefs of users}

In this category, the participants highlighted that they recognize the user's beliefs and spiritual values during the period of hospitalization. According to the workers statements, there is a genuine interest of the team in considering the beliefs and values that compose the patient's life.

We ask and talk about this, what each one believes, if they are practicing, or not in their religion(E1).

Identifying the patient's beliefs and seeing what they believe, what they can invest in relation to spirituality (E4).

It is to respect the beliefs and values of each person, each patient. We have to respect and consider what the patient believes, what he thinks is good for him (E5).

It is to respect the belief of our patient regardless of what it is (E12).

The team demonstrates being attentive and willing to know the beliefs and values that are part of the patient's life and to understand the role that they play in helping them cope with anxiety during hospitalization. It is important to understand the role that beliefs and values play in one's life without judging or attempting to modify them.

It is important to note that the health worker should provide support and respect when identifying the patient's spiritual and religious beliefs, even in relation to those he or she does not know or which are different from what they are accustomed to encounter, or even in the face of the ones that are conflictive with the treatment itself(6). For health workers, an important purpose of knowing one's history is to reveal and understand the beliefs that guide the patient's life, as shown in the following statements:

Respect the beliefs of patients and that our beliefs are not transmitted to the patient (E3).

Working on the principle that the patient has a belief, on the ways they have lived this belief in their day to day. And how much this belief can make them improve during treatment (E6).
I will not interfere with the patient's spiritual belief and I always ask what their belief is (E8).

The beliefs and spiritual values of users are relevant factors and should be taken into consideration when providing health care. The awareness of health professionals about the importance of spiritual care is an important factor, since by offering it, they are sharing respect, empathy, guidance without criticism or judgment. Spiritual care can be approached by professionals as a strategy to offer comfort, tranquility and well-being to the patient ${ }^{(16)}$.

The participants believe it is important to know and identify the user's spiritual beliefs and values in order to provide a more qualified assistance. In addition, they are careful not to impose their religious beliefs, respecting the uniqueness of the person seeking treatment. It is noteworthy that spiritual care goes beyond knowing and addressing the beliefs of users, but also the worker must find out together with the user how spirituality can be included in their health care.

\section{The health professional-user relationship}

Among the various tools that can be used during hospitalization due to addiction, professionals highlighted that they encourage users to reflect on their way of life, guide them to perform relaxation techniques and prayer practices, always respecting their desire and tolerance.

lencourage relaxation practices, they become much calmer, quiet. (E2)

I direct him to what he needs, doing a relaxation technique. (E8)

You told me it relieves you a lot when you pray, did you do it today? Do you need some time to pray? (E3)

The respiratory relaxation technique consists of breathing control exercise using the diaphragmatic muscle and is performed in three distinct phases of inspiration and expiration. This technique causes a feeling of well-being. This is because, in a relaxed state, a person is less likely to act impulsively, and learning this technique can be a tool to manage the need (craving) and anxiety symptoms ${ }^{(17)}$.

Praying is one of the spiritual practices most used by users to cope with chronic illness. It is observed that the act of praying is frequent and can promote well-being, facilitating coping with the health / disease process, reducing mortality in people with blood infections ${ }^{(18)}$.

In the inpatient addict unit, this relationship between health worker and user occurs daily. And it is important that 
the worker, by approaching and talking to the patient, can try to find out with the person what makes sense in his life, beyond just stopping using drugs. In this context, in one of the statements from interviewees, this search to exercise the reflection on their life and existence is evident.

To motivate patients for their treatment, not because stopping drug use is good, but motivating them to think about their lives. They never had this opportunity to think about their own life, about its value, about their existence and about their role in the world (E3).

Therefore, when the worker encourages the user to reflect on his life, he provides the person with alternatives for a better and healthier way of life. One of the professional tasks is to try to broaden the patient's perception of life, helping them to improve awareness for the discovery of existential values, the search for meaning in life, and the protection of their health ${ }^{(19)}$.

\section{Collective spiritual care}

Over the last decades, group activities have been used as a valuable tool in the treatment of addictions. This is mainly because it helps people to create alternatives for their isolation and loneliness, while offering a mean for the drug user to perceive himself as an integral part of the group, thus being part of a society ${ }^{(20)}$.

The participants reported that they encourage individuals to participate in the meditation, spirituality, and 12-step groups. The meditation group uses mindfulness meditation (guided meditation for the conscious of the inner and outer world of the individual) associated with breathing relaxation exercises. After meditation, a reflection about the experience is always held with the participants, who spontaneously talk about the feelings experienced during this practice. This group is an optional treatment activity where users choose whether to participate or not.

lencourage them to participate in the meditation group (E2).

We greatly encourage meditation, there are patients who have been discharged and continue this practice. It is a way to prevent new addictions, so l am very fan and an adept (E6).

I participate in meditation and contribute to spirituality, with self-knowledge, reflection, so that you can get in touch with yourself (E7).

It is important for health workers to be aware of the importance of encouraging the person to meditate, as many of them have never done so or do not know about this practice, nor its benefits that are already documented in the literature. Then, the health team can offer this technique to the user by exposing them to this experience, offering more choices for the patient in their treatment and thus increasing their possibilities for self-awareness.

Among the meditative approaches, mindfulness meditation is the most studied and practiced today in the western world. The term mindfulness refers to the ability to be aware of the present moment in physical sensations, perceptions, thoughts and feelings, without judgment ${ }^{(19)}$. With the origin in traditions such as Buddhism, yoga and Taoism, its practice was integrated with behavioral medicine, especially in stress reduction programs, and is currently being practiced in the treatment of addictions ${ }^{(21)}$.

The use of mindfulness meditation in a non-religious context, enables anyone to benefit from its practice ${ }^{(21)}$. Perhaps for this reason this is one of the most studied and practiced meditation techniques in the health field.

After a meditation group, the patients leave very calmly (E1).

When there is a meditation group, the patients come in a calmer state (E10).

In agreement with the statements that point to anxiety reduction as one of the effects after meditation, one study found that the mindfulness meditation practice can help a person gain the ability to cope with their emotions, helping to deal with anxieties and cravings related to the drug ${ }^{(21)}$.

Another therapeutic group reported by the interviewees was the spirituality group. They report that in this group a reflection and reorganization of life can be carried out, so that the person's main goal is not only to stop using drugs, but to rethink their beliefs and values.

The patients come out of the spirituality group feeling that the treatment is not just focused in stopping using the substance. They say - I have to review what I believe, what has guided my decisions! (E3).

In the spirituality group I put reflective videos and discuss poetry (E6).

The professional pointed out that the group proposal is not that the patients should focus only on stopping using drug; it aims to encourage the user to broaden their world view in order for them to make their choices and decisions. The spirituality group aims to provide moments of reflection and dialogue about the meaning of life and the importance of self-transcendence in the midst of drug users difficult 
life situations. This is because users who are hospitalized demonstrate an existential void and report feeling lonely, as they have had many family and affective ties lost due to the problems generated by drug abuse.

The spirituality group tries to stimulate change in people's lifestyle through reflection. The following statements are in agreement with the literature of Viktor Frankl, who stated that the primary issue of the human being is the search for meaning in life ${ }^{(22)}$.

Life is more complex, it goes from the survival mode to the existential one (E3).

In the spirituality group we discuss what patients understand about spirituality, what their belief is. It is a moment of reflection (E5).

Participants reported that they encourage patients to reflect on their life during hospitalization, and that this process of rethinking their history may help the person to get out of the "survival mode", a more restricted and limited life focused in drug abuse, for a broader and more complex reflection that involves their lifestyle and existence in the world.

The participants also reported that they encourage patients to participate in the 12-step group, which has as its guiding proposal the philosophy of the Alcoholics Anonymous (AA) mutual aid group. This organization has a religious origin but has broadened its approach to the perspective of spirituality as one of its pillars, accepting participants from all religious and those without religious beliefs.

Participation in AA groups can help the person during drug addiction treatment. From this perspective, the importance of the practice of actions based on spirituality by the individual stand out, such as prayer, meditation and conscious contact with a higher power, which the person chooses according to their belief ${ }^{(23)}$.

Health professionals consider that this philosophy can help users coping with the difficulties of the hospitalization period, considering spirituality as one of the elements that help in maintaining drug treatment.

I like to go to the 12-step group, which covers this part of spirituality (E1).

In the AA group I participate a lot, I talk to them because it is an activity that develops their spirituality (E2).

I believe that the AA group stimulates spirituality and can help in treatment (E9).

The 12-step group is a philosophy of life that addresses spirituality, they have to attend AA after discharge (E11).
In the interviews collected, professionals recognize that the 12-step group is associated with the spiritual dimension of the user, and that this approach may be another tool to assist the person during treatment. For the US National Institute on Drug Abuse ${ }^{(24)}$, participation in AA or other similar groups, during and after treatment, can help maintain drug abstinence. Such experience, even in the hospitalization stage, can serve as a stimulating factor for the attachment and participation in mutual support groups after hospital discharge.

As a result of the CCR method, it was found that this work allowed participants to associate the theory of spiritual care with the practices performed in the service during the research data collection, especially in the moments of conversation and training rounds. In these moments, the participants, along with other service professionals, were able to discuss conceptual aspects of spiritual care associated with the reports of their experiences during the clinical practice in the unit.

An improvement of the spiritual care from the reflections made with the research participants was found, with the recommendations of continuing the rounds of conversation about the theme, carrying out qualifications courses and creating and consolidating a secular space of expression of the spirituality.

This research contributed so the professionals of the service could reflect on their attitudes towards spiritual care, recognizing them and the different actions performed by them in daily routine, further enhancing the scope of spiritual care in the service. It is perceived that nursing professionals benefited most from this discussion since almost all participants were from this area. Another important implication for the service, as one of the expected developments for research of this nature (CCR framework) was the incorporation of the theme "Spirituality and self-care" into the training matrix of the institution's nursing service.

\section{口 FINAL CONSIDERATIONS}

Offering spiritual care in addiction involves being with the addict, both as a affective presence aiming to serve, but it also involves the spiritual needs of this user who suffers with drug abuse. Professionals seek to respect the uniqueness of users and to find together with them strategies to assist in the difficulties faced with drug use. Among these strategies, they stimulate reflection on their way of living life by performing relaxation techniques and prayer, according to the desire of users. In addition, the professionals guide them to participate in spiritual connotation therapeutic groups such as meditation, spirituality and 12 step AA groups. 
This study highlighted the concern of professionals in the field to identify the needs of drug users, through attentive listening, sincere dialogue and the establishment of an affective bond in order to perform qualified and individualized care that values the spiritual needs.

In the context of health services, the importance of the continuation and maintenance of spaces of permanent education on spirituality in the treatment of drug addiction is emphasized, furthering their understanding and the continuity of spiritual care. In addition, it is noteworthy that the residents (in uni-professional or multiprofessional health residencies) who have a great workload in the service were not cited by the team as promoters of spiritual care, and therefore it is important to warn the managers about teaching practices about the relevance of the theme for the training of health workers specialized in the area of addiction.

The original objective of this study was to listen to professionals from different categories about spiritual care, however, it was found that nursing professionals are the ones who were most involved and recognized as promoters of this care practice, which was considered to be a limitation of this study, since the results cannot be transposed to the multiprofessional team. It is suggested that further studies on spirituality be carried out in other drug treatment services in addition to studies that include users as participants, as they are the ones most interested in having their needs met.

\section{DEFERENCES}

1. Bastos FIPM,Vasconcellos MTL, De Boni RB, Reis NB, Coutinho CFS, organizadores. III levantamento nacional sobre 0 uso de drogas pela população brasileira. Rio de Janeiro: FIOCRUZ/ICICT; 2017 [cited 2019 Aug 18]. Available from: https:// www.arca.fiocruz.br/handle/icict/34614

2. Presidência da República (BR). Lei no 11.343, de 23 de agosto de 2006. Institui 0 Sistema Nacional de Políticas Públicas sobre Drogas - Sisnad; prescreve medidas para prevenção do uso indevido, atenção e reinserção social de usuários e dependentes de drogas; estabelece normas para repressão à produção não autorizada e ao tráfico ilícito de drogas; define crimes e dá outras providências. Diário Oficial da União. 2006 ago 24 [cited 2019 Aug 18];150(163 Seção 1):2-6. Available from: http://pesquisa.in.gov.br/imprensa/jsp/visualiza/index.jsp?dat $\mathrm{a}=24 / 08 / 2006 \&$ jornal $=1 \&$ pagina $=2 \&$ totalArquivos $=200$

3. Shamsalina A, Norouzi K, Fallahi Khoshknab M, Farhoudiyan A. Recovery based on spirituality in substance abusers in Iran. Glob J Health Sci. 2014; 6(6):15462. doi: https://doi.org/10.5539/gjhs.v6n6p154
4. Koenig HG. Espiritualidade no cuidado com o paciente: por quê, como, quando e 0 quê. $2^{a}$ ed. São Paulo: FE; 2012.

5. Puchalski $C M$, Ferrel B. Making health care hole: integrating spirituality into patient care. Pennsylvania: Templeton; 2010.

6. Koenig HG. Medicina, religião e saúde: 0 encontro da ciência e da espiritualidade. Porto Alegre: L\&PM; 2015.

7. Trentini M, Paim L, Silva DMGV. Pesquisa convergente assistencial (PCA): delineamento provocador de mudanças nas práticas de saúde. Porto Alegre: Moriá; 2014.

8. Flores $\mathrm{GE}$, Oliveira $\mathrm{DLL}$, Zocche DAA. Educação permanente no contexto hospitalar: a experiência que ressignifica o cuidado em enfermagem. Trab Educ Saúde. 2016;14(2):487-504. doi: https://doi.org/10.1590/1981-7746sip00118

9. Veloza-Gómez M, Munõz de Rodríguez L, Guevara-Armenta C, MesaRodríguez $\mathrm{S}$. The importance of spiritual care in nursing practice. J Holist Nurs. 2017;35(2):118-31. doi: https://doi.org/10.1177/0898010115626777

10. Caldeira S, Timmins F. Implementing spiritual care interventions. Nurs Stand. 2017;31(34):54-60. doi: https://doi.org/10.7748/ns.2017.e10313

11. Ramezani M, Ahmadi F, Mohammadi E, Kazemnejad A. Spiritual care in nursing: a concept analysis. Int Nurs Rev. 2014;61(2):211-9. doi: https://doi. org/10.1111/inr.12099

12. Bard ND, Antunes B, Roos CM, Olschowsky A, Pinho LB. Stigma and prejudice: the experience of crack users. Rev Latino-Am Enfermagem. 2016;24:e2680. doi: https://doi.org/10.1590/1518-8345.0852.2680

13. Lavorato-Neto G. Rodrigues L, Turato ER, Campos CJG. The free spirit: spiritualism meanings by a Nursing team on psychiatry. Rev Bras Enferm. 2018;71(2):280-8. doi: https://doi.org/10.1590/0034-7167-2016-0428

14. Figlie NB, Guimarães LP. A entrevista motivacional: conversas sobre mudança. Bol Acad Paul Psicol. 2014 [cited 2019 Aug 18];34(87):472-89. Available from: http://pepsic.bvsalud.org/scielo.php?script=sci_arttext\&pid=\$1415$711 \times 2014000200011$

15. Nascimento LC, Santos TFM, Oliveira FCS, Pan R, Flória-Santos M, Rocha SMM. Spirituality and religiosity in the perspectives of nurses. Texto Contexto Enferm. 2013;22(1):52-60. doi: https://doi.org/10.1590/5010407072013000100007

16. Rusa SG, Peripato GI, Pavarini SCI, Inouye K, Zazzetta MS, Orlandi FS. Quality of life/spirituality, religion and personal beliefs of adult and elderly chronic kidney patients under hemodialysis. Rev Latino-Am Enfermagem. 2014;22(6):911-7. doi: https://doi.org/10.1590/0104-1169.3595.2495

17. Brasileiro TOZ, Prado AAO, Assis BB, Nogueira DA, Lima RS, Chaves ECL. Effects of prayer on the vital signs of patients with chronic kidney disease: randomized controlled trial. Rev Esc Enferm USP. 2017;51:e03236. doi: https://doi. org/10.1590/S1980-220X2016024603236

18. Braga JEF, Chaves Neto G, Lima AB, Oliveira RQ, Alves RS, Farias JA. Jogos cooperativos e relaxamento respiratório: efeito sobre craving e ansiedade. Rev Bras Med Esporte. 2016;22(5):403-7. doi: https://doi.org/10.1590/1517869220162205153151

19. Kabat-Zinn J. Full catastrophe living: how to cope with stress, pain and illness using mindfulness meditation. Revised ed. London: Piatkus; 2013. 
20. Sobell LC, Sobell MB. Terapia de Grupo para transtorno por abuso de substâncias: abordagem cognitivo-comportamental motivacional. Porto Alegre: Artmed; 2013.

21. Tang $Y Y$, Tang R, Posner IM. Mindfulness meditation improves emotion regulation and reduces drug abuse. Drug Alcohol Depend. 2016;163(Suppl 1):S13-8. doi: https://doi.org/10.1016/j.drugalcdep.2015.11.041

22. Aquino TAAA. Sentido da vida e valores no contexto da educação: uma proposta de intervenção à luz do pensamento de Viktor Frankl. São Paulo: Paulinas; 2015.

23. Payá R, coordenadora. Intervenções familiares para 0 abuso e dependência de álcool e outras drogas. Rio de Janeiro: Roca; 2017.
24. National Institute on Drug Abuse. Principles of drug addiction treatment for criminal justice populations: a research based guide. Bethesda: NIH; 2014 [cited 2019 Aug 10]. Available from: https://d14rmgtrwzf5a.cloudfront.net/sites/ default/files/txcriminaljustice_0.pdf

\section{Acknowledgment:}

To the Coordination of Superior Level Staff Improvement (CAPES).

\section{Corresponding author:}

Charlise Pasuch de Oliveira

Email: Charlise.pasuch@gmail.com

Associate editors:

Ana Karina Silva da Rocha Tanaka

Editor-in-chief:

Maria da Graça Oliveira Crossetti 